\title{
Reef Flat Community Structure of Atol das Rocas, Northeast Brazil and Southwest Atlantic
}

\author{
Adriana C. Fonseca, ${ }^{1,2}$ Roberto Villaça, ${ }^{3}$ and Bastiaan Knoppers ${ }^{2}$ \\ ${ }^{1}$ Instituto Chico Mendes de Conservação da Biodiversidade (ICMBIO), Rodovia Mauricio S. Sobrinho s/n ${ }^{\circ}, \mathrm{km} \mathrm{2,}$ \\ 88053-700, Florianópolis, SC, Brazil \\ ${ }^{2}$ Programa de Pós-Graduação em Geoquímica, Instituto de Química, Universidade Federal Fluminense, \\ Outeiro de São João Batista, s/n $24020-141$, Niterói, RJ, Brazil \\ ${ }^{3}$ Programa de Pós-Graduação em Biologia Marinha, Instituto de Biologia, Universidade Federal Fluminense, \\ Outeiro de São João Batista, s/n², 24001-970, Niterói, RJ, Brazil
}

Correspondence should be addressed to Adriana C. Fonseca, adricarvalhal@globo.com

Received 20 March 2012; Accepted 29 May 2012

Academic Editor: Jakov Dulčić

Copyright ( $\odot 2012$ Adriana C. Fonseca et al. This is an open access article distributed under the Creative Commons Attribution License, which permits unrestricted use, distribution, and reproduction in any medium, provided the original work is properly cited.

This study was conducted during 1999 to 2002 and addresses the community structure and some ecological aspects of the benthic reef flat assemblages of Atol das Rocas, located offshore the NE brazilian coast. It corresponds to the sole atoll of the SW Atlantic, which characterized by a shallow topography and is almost completely built by coralline algae. The turf forming red macroalgae Digenea simplex and the crustose coralline Hydrolithon pachydermum were the dominant species of the reef flat. The crustose green macroalgae Dictyosphaeria ocellata and the turf forming red macroalgae Gelidiella acerosa were the subdominant species. Biomass values of $D$. simplex were about twice higher than the other species, pointing out to its relevance in the community structure of this reef zone. Biodiversity indices indicated a high equitability within the few species observed and a relative temporal stability of the community structure. Some local spatial variations were found in the community structure of the reef flat zone, enabling the definition of three subhabitats. The patterns of distribution and abundance of the benthic organisms seem to be related to the environmental conditions of the reef flat, such as low water turbulence, lengthy periods of aerial exposure, and low herbivore pressure.

\section{Introduction}

Reefs of tropical atolls have been described as harboring welldefined geomorphic zones, including a fore-reef, a reef crest, a reef flat, and a lagoonal reef zone [1-3]. Theoretically, each zone is subject to intrinsic environmental conditions which circumscribe unique habitat types and communities. Benthic communities within each zone were thought to exhibit a great similarity between each other. However, local small scale variability of physical and biotic factors in a well-defined geomorphic zone may harbor microcosms, each supporting unique benthic communities [4-6].

The reef flat zone is a complex area with gradients of environmental factors such as temperature, turbidity, and tidal related exposure of communities [3]. These gradients coupled with differences in depth and substrate type provide a great number of habitats that have resulted in subdivisions of this zone [7-10]. For further understanding of the similarities and differences within this geomorphic zone, it becomes essential to obtain more information on the organization of the benthic community assemblages and how they operate in accordance to the physical-geomorphological features of their habitats [11].

The Marine Biological Reserve of Atol das Rocas, NE Brazil, is a pristine reef area which offers an ideal system to study natural variations of benthic community assemblages within geomorphic zones. The reserve was created in 1979 encompassing a region of about $360 \mathrm{~km}^{2}$ around the reef ring formerly reaching depths down to about $1.000 \mathrm{~m}$. In contrast to the atolls of the Indo-Pacific and Caribbean waters, mainly constructed by hermatypic corals, the reef framework of Atol das Rocas is largely composed of crustose coralline algae, foraminiferans, and shells of mollusk gastropods [12, 13]. 


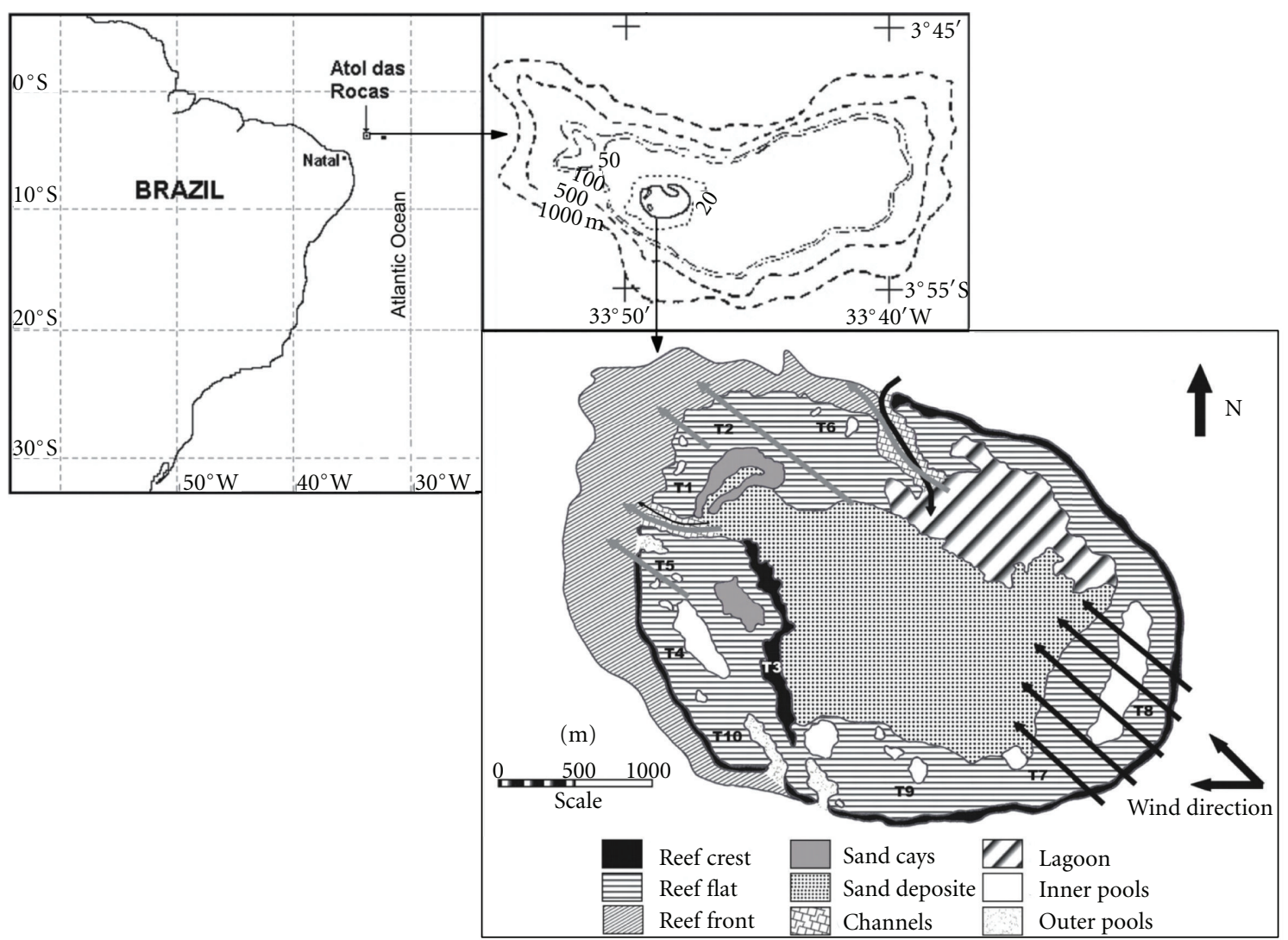

Figure 1: Study area showing the sampling sites on the reef flat (T1-T10) and the pattern of internal current circulation: black arrows = flood tide, gray arrows $=$ ebb tide.

In Atol das Rocas, frondose macroalgae, algal turfs, and coralline algae are the major space occupiers in many benthic areas $[14,15]$. Until now, however, few studies focused on benthic community assemblages of Atol das Rocas [13, 16-18] and none of these assessments included the algal communities as a whole.

The present paper addresses the benthic communities with emphasis on the algal assemblages of the reef flat zone of Atol das Rocas. The main goals were to determine (1) the distribution and abundance of benthic organisms; (2) the communities' structure and diversity; (3) the spatial and seasonal similarities between the benthic assemblages; (4) also infer about the environmental factors that govern the distribution and abundance of benthic organisms. The results should help to understand the organization of benthic communities in the reef flat giving support to the management of the marine reserve of Atol das Rocas.

\section{Material and Methods}

2.1. Study Area. Atol das Rocas is located in the Southwest Atlantic Ocean at $3^{\circ} 51^{\prime} \mathrm{S}$ and $33^{\circ} 49^{\prime} \mathrm{W}, 266 \mathrm{~km}$ offshore from the city of Natal, Rio Grande do Norte State, NE Brazil (Figure 1). It corresponds to the sole atoll in the South Atlantic and is one of the smallest atolls in the world. It has an elliptical shape, measuring $3,5 \mathrm{~km}$ along its main $\mathrm{E}-\mathrm{W}$ axis and $2,5 \mathrm{~km}$ along its $\mathrm{N}-\mathrm{S}$ axis. The reef flat proper has a total area of about $2,62 \mathrm{~km}^{2}$ with a width varying between 100 and $800 \mathrm{~m}$. The reef flat surface is composed by associations of coralline algae-vermetid gastropods growing as linear ridges with an elevation of around $2 \mathrm{~m}$ above the Mean Seawater Level (MSL). Its contour is almost continuous, being interrupted by two tidal channels to the ocean, one set at the western and the other at the northern flank. These channels divide the reef flat into a windward and a leeward arch. An algal dominated reef crest of about $5 \mathrm{~m}$ wide and height of up to $0.5 \mathrm{~m}$ above the reef flat surface limits the entire windward arch. At the leeward side, this feature is almost inexistent [12,13,19] (Figure 1). The windward arch presents higher elevations than the leeward one, since the geological development of the former is older than the latter $[19,20]$.

The South Equatorial Current (SEC) and SE to E trade winds dominate the Rocas area. SEC has a constant westward drift with a mean speed of $30 \mathrm{~cm} \mathrm{~s}^{-1}$ and the winds attain maximum speeds of $11 \mathrm{~m} \mathrm{~s}^{-1}$ (13 and others cited therein). Waves pound largely upon the eastern windward portion of the atoll at periods of $4 \mathrm{~s}$ to $7 \mathrm{~s}$ and heights not beyond $2 \mathrm{~m}$. However, in summer months (December to March), when the Intertropical Convergence Zone (ITCZ) crosses the equator and attains its southernmost position, higher waves with longer periods emerge from the North Atlantic on the leeward side of the atoll (19 and others cited therein). The regional climate is tropical and dry, with a minimum 
air temperature of $26^{\circ} \mathrm{C}$ and annual average precipitation of $109 \mathrm{~mm}$ [21].

Local tides are semidiurnal and attain a maximum range of $3,8 \mathrm{~m} \mathrm{[13]}$. At flood tide, water flows into the reef through the northern channel and over the windward side of the reef flat. At ebb tides, water outflow to the sea occurs via both the northern and western channels [16] (Figure 1). The reef flat is entirely emerged during low tide and submerged at high tide. Surface water temperatures at the fore reef vary between $27^{\circ} \mathrm{C}$ and $29^{\circ} \mathrm{C}$ and salinities between 36 and 38. In shallow waters of the back reef, the water temperature may vary from $24^{\circ} \mathrm{C}$ to $36^{\circ} \mathrm{C}$ and salinities from 36 to 42 .

2.2. Sampling. The biological data were obtained from four (three-weekly) field surveys, being two set in "austral winter" (July 1999 and June 2000) and two in "austral summer" (December 2000 and March 2002). The abundance of benthic organisms was estimated as the percentage cover at 10 different sites (T1 to T10) on the reef flat (Figure 1). At each site, 15 quadrat frames, with a size of $25 \times 25 \mathrm{~cm}$ each, were set in a distance of five meters between each other, forming a grid. Each grid, corresponded to a total area of $93,7 \mathrm{~m}^{2}$ and was set between the reef crest and the inside edge of the reef flat. The quadrats were sampled by a visual estimate method [22]. The site positions were marked by GPS (Garmin Etrex) and manually positioned local markings and revisited during each campaign. The standing stock of the most representative macroalgal species of the reef flat was estimated using percentage cover-biomass (dry weight) conversion factors. To obtain the factors, the total cover of each macroalgae species (wet-weight) was scratched from some quadrats and the constant dry weight asserted in the laboratory. At least five samples were obtained for each species and mean factors were computed. The standing stock of each species on the reef flat was thus estimated using mean percentage cover data.

2.3. Data Analysis. Biological variables such as the Shannon Index of Diversity $\left(\mathrm{H}^{\prime}\right)$, Taxonomic Richness, and Evenness (Pielou's J) [23] were calculated for each site of the reef flat, and campaign. The similarity between sites was analyzed by nonmetric multidimensional scaling ordination (MDS), driven by taxa percentage cover data (by square-root transformation) and the Bray-Curtis index. Formal significance tests for differences between the groups were performed using the 1-way ANOSIM test. The taxa contributing for the similarity of the groups and the dissimilarities within them were investigated using the similarities percentages procedure (SIMPER). The statistical package PRIMER 6.0 (Primer-E) was used for these analyses.

Seasonal differences in taxa cover in the different habitats were tested using 1-way ANOVA. These biological data were determined by averaging site data. Bartlett's test was used to test normality and where necessary, data were $\log (x+1)$ transformed or the nonparametric Kruskal-Wallis test was applied. The post hoc multiple comparisons tests
Tukey-Kramer, for parametric data, and Dunn's, for nonparametric data, were used when significant differences were detected $(p<0.05)$ [24]. The statistical package GraphPad Instat (GraphPad Software) was used.

\section{Results}

3.1. Benthic Community Structure. The reef flat benthic community presents a physiognomic monotony, with few taxa replacing each other amongst the different sites. During all surveys only twenty taxa were recorded, being the macroalgae the dominant organisms (Table 1). The overall Shannon Index $\left(\mathrm{H}^{\prime}\right)$ ranged between 2,75 and 3,18, Richness between 13 and 16, and Evenness (Pielou's J) between 0,70 and 0,84 (Table 2).

The benthic community stands were, in general, bi- or tri-stratified, composed by a crustose and an erect stratum with less than $10 \mathrm{~cm}$ in height. The erect stratum is basically formed by turf-like mat species, mainly the Rodophyceae Digenea simplex (17-29\%) and Gelidiella acerosa (7-14\%). The crustose stratum was mainly composed by the red coralline Hydrolithon pachydermum (15-30\%) and the Chlorophyceae Dictyosphaeria ocellata (10-29\%). These four species achieved together $68 \%$ to $95 \%$ of the total benthic cover on the reef flat. The biomass data exhibited values of about $969 \mathrm{~g} \mathrm{dw} \mathrm{m}^{-2}$ for D. simplex, $484 \mathrm{~g} \mathrm{dw} \mathrm{m}^{-2}$ for $D$. ocellata, and $274 \mathrm{~g} \mathrm{dw} \mathrm{m}^{-2}$ for G. acerosa. Figure 2 shows the variations of biomass estimates for these species in the reef flat as a whole.

Despite the dominance of macroalgae, sessile fauna were also important. The zoanthid Zoanthus sociatus dominates great areas of the reef flat (18-20\%), showing high competitive abilities, as in certain places all others organisms were absent. Other important components of the reef benthic fauna were the encrusting tube worms $(0,2-14 \%)$ and the mollusc Vermetidae Dendropoma sp. (0,2-6\%), which participates in reef construction as secondary framework builders $[12,13]$. Though the majority of taxa, either of the flora and the invertebrates, were distributed along almost the entire reef flat, some exceptions, such as G. acerosa and G. setacea, were more restricted to specific sites, mainly in the leeward reef flat.

3.2. Data Analysis. The MDS ordinations of taxa cover on the reef flat identified four major groups, mainly reflecting spatial differences of the community structure along this reef zone (Figure 3). Group I, composed the sites T1, T2, and T10; group II, mainly the sites T3, T5, and T6, and groups III and IV, the sites T4, T7, T8, and T9. The results of the ANOSIM tests confirmed the differences between the groups $(R=0,879 ; p=0,001)$. The pairwise tests showed that the most significant differences were between group I and the remainder (Table 3).

The Similarity Percentage Analysis (SIMPER) showed that variations on the cover of Digenea simplex, Gelidiella acerosa, Zoanthus sociatus, polychaeta tubes, and cyanobacteria (Lyngbya confervoides and another nonidentified species) contributed most to the break-down of similarity between 
TABLE 1: Mean cover of benthic species recorded in Atol das Rocas reef flat. The values correspond to the mean of the 10 sites sampled. Algae nomenclatures are in accordance with AlgaeBase (2009). Other species in accordance with Catalogue of Life (2009).

\begin{tabular}{|c|c|c|c|c|}
\hline \multirow{2}{*}{ Species } & \multicolumn{4}{|c|}{ Mean cover $(\%) \pm S D$} \\
\hline & Winter 1999 & Winter 2000 & Summer 2000 & Summer 2002 \\
\hline \multicolumn{5}{|l|}{ Bacteria } \\
\hline Cyanophyceae (sp.1) & $5.7 \pm 7.6$ & $2.9 \pm 4.1$ & $8.2 \pm 5.3$ & $4.8 \pm 7.8$ \\
\hline Lyngbya confervoides & $2.5 \pm 5.8$ & $10.5 \pm 15.3$ & $0.2 \pm 0.6$ & $7.6 \pm 19.4$ \\
\hline \multicolumn{5}{|l|}{ Plantae } \\
\hline \multicolumn{5}{|l|}{ Chlorophyta } \\
\hline Cladophoropsis membranacea & $0.6 \pm 1.9$ & $0.2 \pm 0.7$ & $0.1 \pm 0.4$ & $1.5 \pm 2.9$ \\
\hline Phyllodictyon anastomosans & - & - & $0.1 \pm 0.2$ & - \\
\hline Dictyosphaeria ocellata & $21.1 \pm 19.4$ & $23.1 \pm 17.3$ & $29.0 \pm 22.1$ & $9.6 \pm 11.2$ \\
\hline Dictyosphaeria versluysii & $0.1 \pm 0.1$ & $0.2 \pm 0.3$ & $0.3 \pm 0.7$ & $3.7 \pm 7.0$ \\
\hline Rhizoclonium sp. & $1.3 \pm 2.2$ & $0.1 \pm 0.2$ & - & - \\
\hline \multicolumn{5}{|l|}{ Rhodophyta } \\
\hline Digenea simplex & $29.2 \pm 34.0$ & $28.5 \pm 31.8$ & $17.3 \pm 24.9$ & $29.3 \pm 28.7$ \\
\hline Herposiphonia secunda & - & $1.1 \pm 2.7$ & - & - \\
\hline Gelidiella acerosa & $14.1 \pm 24.4$ & $13.0 \pm 22.7$ & $9.1 \pm 14.7$ & $7.5 \pm 20.0$ \\
\hline Gelidiella setacea & $2.5 \pm 4.0$ & $3.0 \pm 7.3$ & $1.3 \pm 2.3$ & $1.3 \pm 2.3$ \\
\hline Corallinaceae (sp.1) & $0.2 \pm 0.8$ & $0.1 \pm 0.2$ & $0.1 \pm 0.4$ & - \\
\hline Hydrolithon pachydermum & $15.1 \pm 12.6$ & $30.1 \pm 21.3$ & $27.7 \pm 19.3$ & $22.0 \pm 15.9$ \\
\hline Jania adhaerens & $0.3 \pm 0.1$ & - & - & $2.4 \pm 5.1$ \\
\hline \multicolumn{5}{|l|}{ Phaeophyta } \\
\hline sp. 1 (crustose form) & $5.9 \pm 18.5$ & - & - & - \\
\hline \multicolumn{5}{|l|}{ Animalia } \\
\hline Zoanthus sociatus & $18.2 \pm 28.3$ & $17.9 \pm 22.9$ & $19.9 \pm 27.4$ & $18.0 \pm 28.5$ \\
\hline Siderastrea stellata & $0.1 \pm 0.1$ & - & - & - \\
\hline Dendropoma sp. & $2.1 \pm 4.6$ & $0.2 \pm 0.6$ & $5.8 \pm 9.4$ & - \\
\hline Plakortis sp & - & - & $0.3 \pm 0.6$ & $1.2 \pm 1.9$ \\
\hline Polychaeta (sp.1-encrusting tube worm) & $12.1 \pm 16.4$ & $14.5 \pm 21.3$ & $0.2 \pm 0.8$ & $7.9 \pm 13.5$ \\
\hline
\end{tabular}

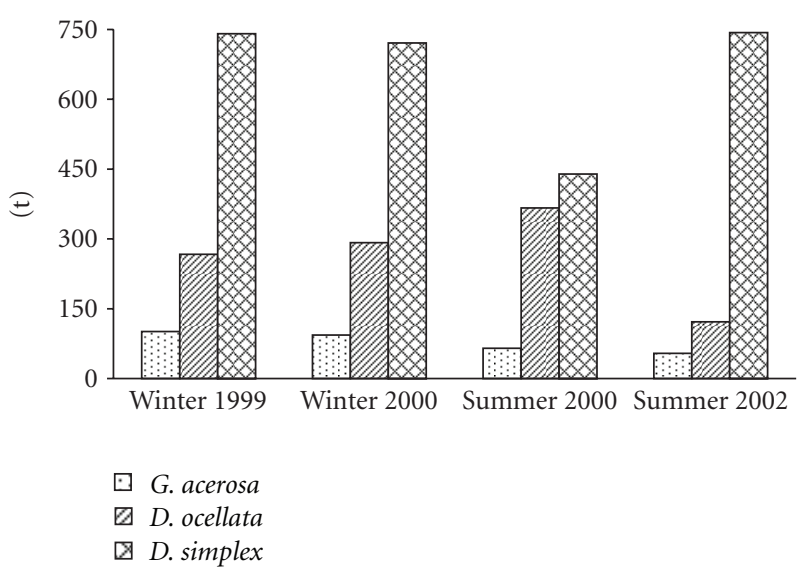

FIGURE 2: Biomass variation of the most representative macroalgae species, Gelidiella acerosa, Dictyosphaeria ocellata, and Digenea simplex, on the entire reef flat. The values correspond to the mean of the 10 sites sampled.

the groups (Table 4). The most important taxa in characterizing group I were $Z$. sociatus and G. acerosa. D. simplex was the dominant of group II. Hydrolithon pachydermum was well represented in all groups, but more relevant in groups III and IV. Dictyosphaeria ocellata occurred in both groups III and IV and L. confervoides and polychaeta tubes in group IV.
Although the variance analyses pointed out to some significant differences $(p<0,05$ and $p<0,01)$ in taxa coverage between the different sampling periods, it could not be attributed to a clear seasonal pattern, being more likely to local differences in the degree of patchiness. MDS ordination also revealed some differences in taxa cover in summer 2000 for sites T4, T7, T8, and T9 (group III of MDS). SIMPER 
TABle 2: Diversity data within the ten sampling sites: Shannon index $\left(H^{\prime}\right)$, Species Richness $(S)$, and Pielous's Evenness $(J)$; W99 = winter 1999, W00 = winter 2000, S00 = summer 2000, S02 = summer 2002.

\begin{tabular}{|c|c|c|c|c|}
\hline & Stations of years & $(S)$ & $\left(H^{\prime}\right)$ & $(J)$ \\
\hline \multirow{4}{*}{ Site 1} & W99 & 7.00 & 1.59 & 0.57 \\
\hline & W00 & 8.00 & 1.50 & 0.50 \\
\hline & S00 & 6.00 & 1.91 & 0.74 \\
\hline & S02 & 6.00 & 1.79 & 0.69 \\
\hline \multirow{3}{*}{ Site 2} & W99 & 8.00 & 2.33 & 0.78 \\
\hline & W00 & 7.00 & 2.44 & 0.87 \\
\hline & S00 & 7.00 & 2.44 & 0.87 \\
\hline \multirow{4}{*}{ Site 3} & W99 & 5.00 & 0.94 & 0.40 \\
\hline & W00 & 7.00 & 1.31 & 0.47 \\
\hline & S00 & 7.00 & 1.78 & 0.63 \\
\hline & S02 & 7.00 & 1.73 & 0.62 \\
\hline \multirow{3}{*}{ Site 4} & W99 & 7.00 & 1.96 & 0.70 \\
\hline & W00 & 8.00 & 2.22 & 0.74 \\
\hline & S00 & 5.00 & 1.67 & 0.72 \\
\hline \multirow{4}{*}{ Site 5} & W99 & 8.00 & 1.83 & 0.61 \\
\hline & W00 & 7.00 & 2.02 & 0.72 \\
\hline & S00 & 7.00 & 2.22 & 0.79 \\
\hline & S02 & 5.00 & 1.30 & 0.56 \\
\hline \multirow{4}{*}{ Site 6} & W99 & 7.00 & 2.19 & 0.78 \\
\hline & W00 & 8.00 & 2.26 & 0.75 \\
\hline & S00 & 11.00 & 2.22 & 0.64 \\
\hline & S02 & 7.00 & 2.00 & 0.71 \\
\hline \multirow{4}{*}{ Site 7} & W99 & 5.00 & 1.82 & 0.79 \\
\hline & W00 & 4.00 & 1.92 & 0.96 \\
\hline & S00 & 5.00 & 1.94 & 0.83 \\
\hline & S02 & 5.00 & 1.64 & 0.71 \\
\hline \multirow{4}{*}{ Site 8} & W99 & 6.00 & 2.10 & 0.81 \\
\hline & W00 & 5.00 & 2.16 & 0.93 \\
\hline & S00 & 6.00 & 1.74 & 0.68 \\
\hline & S02 & 8.00 & 2.61 & 0.87 \\
\hline \multirow{4}{*}{ Site 9} & W99 & 6.00 & 2.43 & 0.94 \\
\hline & W00 & 7.00 & 2.31 & 0.82 \\
\hline & S00 & 5.00 & 1.44 & 0.62 \\
\hline & S02 & 7.00 & 2.26 & 0.81 \\
\hline \multirow{4}{*}{ Site 10} & W99 & 10.00 & 2.29 & 0.69 \\
\hline & W00 & 8.00 & 2.33 & 0.78 \\
\hline & S00 & 6.00 & 1.84 & 0.71 \\
\hline & S02 & 8.00 & 1.80 & 0.60 \\
\hline \multirow{4}{*}{ Overall } & W99 & 16.00 & 3.18 & 0.80 \\
\hline & W00 & 15.00 & 2.98 & 0.76 \\
\hline & S00 & 15.00 & 2.75 & 0.70 \\
\hline & S02 & 13.00 & 3.12 & 0.84 \\
\hline
\end{tabular}

analyses revealed that these were attributed to variations in the cover of the polychaeta tubes and cyanobacteria. Nevertheless, these patterns were not observed in summer 2002. As such, it is assumed that these were not brought about by seasonal variability, but more likely due to more
TABLE 3: R-statistic values for the global ANOSIM and significance of pairwised tests for differences in community structure between reef flat groups of stations.

\begin{tabular}{lcc}
\hline Global test & $R$ & $p$ \\
& 0.879 & 0.001 \\
\hline Pairwised tests & & \\
$1 \times 2$ & 0.912 & 0.001 \\
$1 \times 3$ & 0.998 & 0.001 \\
$1 \times 4$ & 1 & 0.001 \\
$2 \times 3$ & 0.490 & 0.003 \\
$2 \times 4$ & 0.780 & 0.001 \\
$3 \times 4$ & 0.991 & 0.002 \\
\hline
\end{tabular}

specific short term local variability of the organisms at the individual sampling sites.

3.3. Benthic Community Habitats. The groups defined by the statistical analysis were considered as distinct habitats. However, groups III and IV were considered as a single habitat, as both included T4, T7, T8, and T9 differing only for the summer 2000 campaign in the cover of polychaeta tubes and cyanobacteria. As such three main habitats could be defined for Atol das Rocas reef flat.

Habitat I was characterized by a large coverage of the zoanthid $Z$. sociatus (41-57\%) along with the turf forming red algae Gelidiella acerosa (29-47\%) (Figure 4(a)). A particular feature of this habitat is the absence of the turf forming red macroalgae Digenea simplex. The Shannon Index $\left(\mathrm{H}^{\prime}\right)$ ranged between 1,50 and 2,44, Richness 6 and 10, and Evenness between 0,50 and 0,87.

Habitat II was dominated by the turf forming $D$. simplex with a coverage of $67-72 \%$. In contrast to Habitat I, G. acerosa was absent (Figure $4(\mathrm{~b})$ ). The Shannon Index $\left(\mathrm{H}^{\prime}\right)$ ranged between 0,94 and 2,26, Richness between 5 and 11, and Evenness between 0,40 and 0,79.

Habitat III was composed by a high cover of the crustose coralline Hygrolithon pachydermum (23-48\%) along with the crustose flesh macroalgae Dictyosphaeria ocellata $(17-51 \%)$. The presence of polychaeta $(1-29 \%)$ and the cyanobacteria Lyngbya confervoides $(0,5-26 \%)$ was also relevant (Figure $4(\mathrm{c})$ ). The Shannon Index $\left(\mathrm{H}^{\prime}\right)$ ranged between 1,44 and 2,61, Richness between 4 and 8, and Evenness between 0,62 and 0,96 .

\section{Discussion}

4.1. Benthic Community Structure. Atol das Rocas is the sole atoll of the South Atlantic Ocean. It corresponds to one of the world's smallest atolls with a reef flat set about $2 \mathrm{~m}$ above MSL and an enclosed lagoon type system. The reef flat exhibits a great scarcity of hermatypic coral species and cover and is near to solely dominated by turf forming and crustose macroalgae species. Kikuchi and Leão [19] considered the lack of hermatypic corals as the most striking feature of Atol das Rocas, when compared to other Atlantic and Pacific 

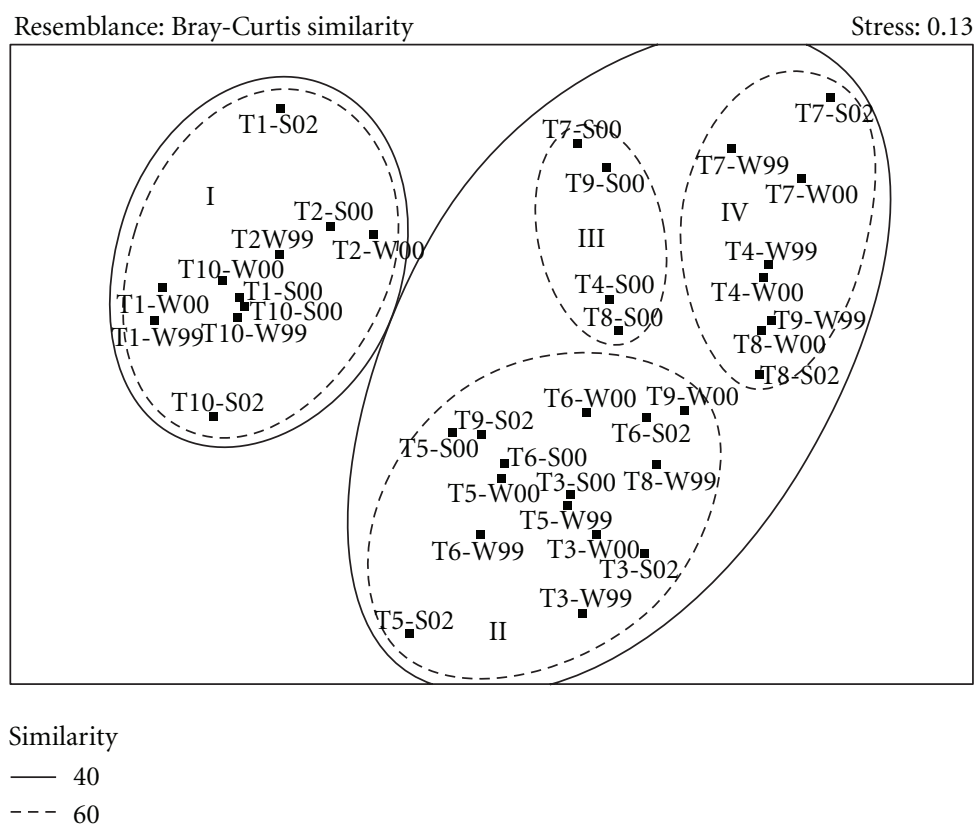

FIGURE 3: MDS ordination of the reef flat stations based on species cover; T1-T10 = sites one to ten; W99= winter 1999, W00 = winter 2000, S00 $=$ summer 2000, S02 = summer 2002.

atolls, where corals dominate most of the reef surface [7, 2527] or at least appear as an important component of the benthic community [11].

The turf forming red macroalgae Digenea simplex and the crustose coralline Hydrolithon pachydermum were the dominant species on most of the Rocas reef flat. The crustose green macroalgae Dictyosphaeria ocellata and the turf forming red macroalgae Gelidiella acerosa were the subdominant species. $D$. simplex exhibited biomass values of about $969 \mathrm{~g} \mathrm{dw} \mathrm{m}^{-2}$, more than twice higher than the subdominant species, corroborating its relevance to the community structure.

In general, the Shannon Index $\left(\mathrm{H}^{\prime}\right)$ showed a relative similarity with other reef flat communities of unpolluted reef areas in Pacific and Caribbean waters, but Richness values were below than those observed in the same areas $[5,8,9]$. On the other hand, the high values of Evenness reflected a relative equitability between the few taxa of the Atol das Rocas reef flat. The small variance of these biological variables between the summer and winter surveys spread over two years suggests that the community structure is subject to stable conditions in time.

As a whole, the main factors controlling the distribution and zonation of benthic organisms within reef systems are wave energy (turbulence of water and abrasion), high light penetration (as a function of depth and low water turbidity), bottom topography, and sedimentation $[2,3,28$, 29]. In open atolls the community structure is strongly influenced by wave action, a product of the prevailing winds [3], and the exposure to oceanic conditions. High physical energy provides an adequate environment for dominance of corals and encrusting calcareous algae [30]. In contrast, the enclosed Atol das Rocas with a reef flat set $2 \mathrm{~m}$ above MSL exhibits a scarcity of coral species and coverage which may be primarily attributed to its high degree of protection from the sea by wave action. According to Kench and Brander [28], reef flats with high elevations above to MSL are efficient in filtering and dissipating wave energy, resulting in a lower potential of geomorphic work, less intense sediment transport, and a higher sediment accumulation within the reef flat. Henceforth, it is expected that the elevated reef flat of Atol das Rocas is also governed by these features. Another striking feature of Atol das Rocas reef flat is the lengthy periods of aerial exposure of the benthic communities, attaining over more than $8 \mathrm{hrs}$ per semidiurnal tidal cycle. The detrimental effects of sedimentation and desiccation on coral diversity and abundance have also been reported elsewhere [3, 7, 30-32].

The high percentage coverage of turf and crustose macroalgae as compared to fleshy macroalgae on the reef flat of Atol das Rocas reflects their ability to successfully colonize and persist under the environmentally unfavorable conditions encountered (i.e., desiccation). The dominance of filamentous and turf forming algae may be attributed to their short generation time, rapid growth rates, opportunistic life histories, and wider tolerance to changing conditions, allowing them to colonize available space rapidly and reach their full growth potential in a shorter time period [30]. Macroalgae that form dense entangled turf may hold water among their branches during exposure, thus, avoiding desiccation $[33,34]$. Also, the few fleshy macroalgae species encountered at the shallow reef flat may have been strongly affected by intense solar radiation, as also reported elsewhere by Morrison [35]. Marques et al. [36] conducted experiments at Atol das Rocas and observed that individuals of some macroalgal species transplanted from the fore reef to the reef flat developed a whitish color, indicative of light damage. 


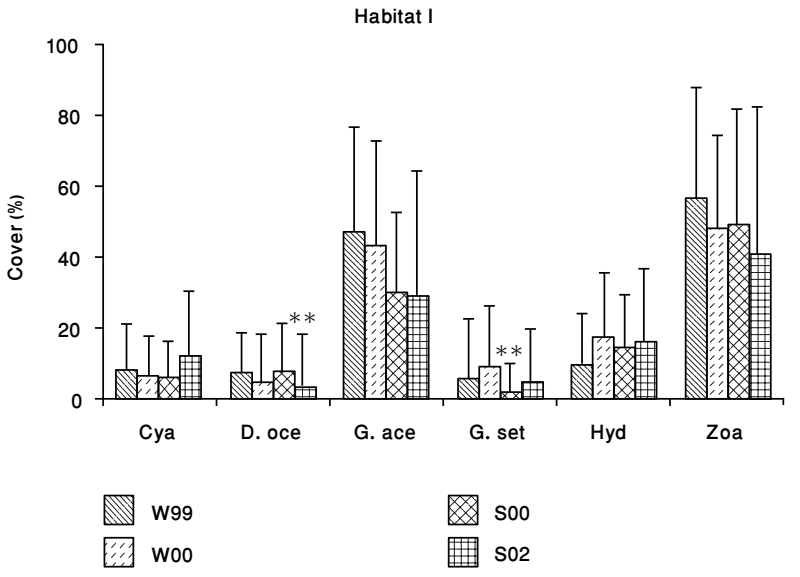

(a)

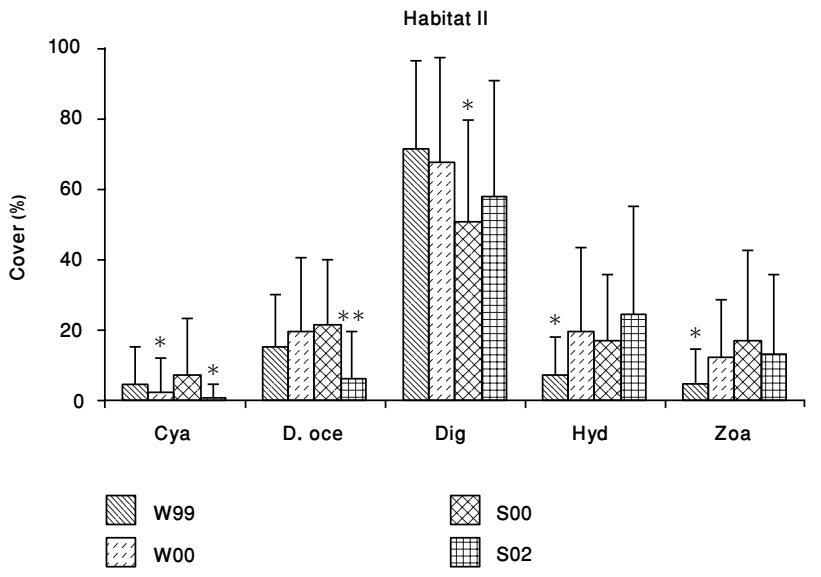

(b)

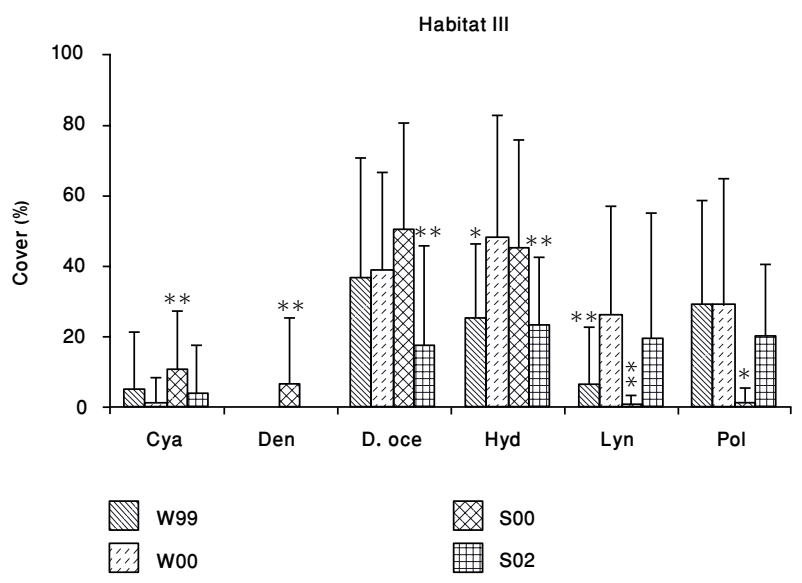

(c)

FIGURE 4: Mean percentage cover and SD for the more representative benthic organisms in the three habitats of the reef flat, pointing the significant post hoc multiple comparisons tests results $\left({ }^{*} p<0.05 ;{ }^{* *} p<0.01\right)$; Cya: Cyanobacteria, Den: Dendropoma sp., Dig: Digenea simplex, D.oce: Dictyosphaeria ocellata, G.ace: Gelidiella acerosa, G.set: Gelidiella setacea, Hyd: Hydrolithon pachydermum, Lyn: Lyngbya confervoides, Pol: Polychaeta tube, Zoa: Zoanthus sociatus; W99: winter 1999, W00: winter 2000, S00: summer 2000, S02: summer 2002.

Another causal agent that may influence the structure of the reef flat benthic community in Atol das Rocas is the low pressure from herbivory, which is considered to play a primary role in determining the distribution and abundance of algae and corals in reef habitats [37-41]. Although the total number of fish species and biomass at Atol das Rocas is similar to other Atlantic islands and small atolls in, for example, French Polynesia [42], several factors argue in favor for a low herbivory upon the benthic habitats within the reef flat, these include (a) the high elevation of the reef flat induces a shallow and bare environment which prevents access of large herbivorous fish and the vulnerability to predators [8]; (b) the low abundance and scarcity of sea urchins represented by only two species Diadema antillarum and Tripneustes variegatus which are restricted to small areas in the lagoon and some pools [36]; (c) only one genus of the coralline algae parrot fish grazer (Sparisoma) seems to play a role within Atol das Rocas [42]. Also, the absence of the more common and powerful grazer of the genus Scarus may play an important role in the enhancement of the coralline algae in the atoll [19], as the grazing activity of parrot fish is one of the most relevant ecological constraints to the development of coralline algae [43].

4.2. Comparisons between Reef Habitats. The statistical analysis revealed the presence of at least three distinct habitats set within the reef flat. The habitats almost harbor the same taxa composition but differ with respect to their abundance. Although environmental conditions were not measured for each specific habitat, the differences observed are likely the result of small scale variations of sedimentation, herbivory, and hydrodynamic conditions.

Observations during samplings of Habitat I, prevailing the leeward arch of the atoll, indicated the presence of high sediment deposition. The leeward side is considered as the youngest geological sector of the atoll and exhibits lower elevation than the windward side $[19,20]$. Consequently, it also might be conditioned to a relatively higher grazing pressure, since the depths during high tide are higher than on the windward side. These conditions promote the development of sediment-resistant species and forms which might be more resistant to grazing pressure. Turf forming 
TABLE 4: Summary results of SIMPER show the percentage contribution of species for the similarity into the groups of station and the dissimilarities within them. Bold type values correspond to species with more than $15 \%$ contribution.

\begin{tabular}{|c|c|c|c|c|c|c|}
\hline Average similarity (\%) & \multicolumn{2}{|c|}{$\begin{array}{c}\text { Group } 1 \\
76.30\end{array}$} & $\begin{array}{c}\text { Group } 2 \\
77.34\end{array}$ & $\begin{array}{c}\text { Group } 3 \\
70.29\end{array}$ & \multicolumn{2}{|c|}{$\begin{array}{c}\text { Group } 4 \\
74.00\end{array}$} \\
\hline \multicolumn{7}{|l|}{ Contribution (\%) } \\
\hline Cyanobacteria & \multicolumn{2}{|c|}{11.93} & 8.90 & 21.88 & & \\
\hline Dendropoma sp. & & & & 7.66 & & \\
\hline Dictyosphaeria ocellata & \multicolumn{2}{|c|}{11.09} & 23.44 & 34.13 & \multicolumn{2}{|c|}{21.27} \\
\hline Digenea simplex & & & 33.75 & & & \\
\hline Gelidiella acerosa & \multicolumn{2}{|c|}{22.67} & & & & \\
\hline Gelidiella setacea & \multicolumn{2}{|c|}{9.92} & & & & \\
\hline Hydrolithon pachydermum & \multicolumn{2}{|c|}{17.53} & 21.09 & 32.46 & \multicolumn{2}{|c|}{27.81} \\
\hline Lyngbya confervoides & & & & & \multicolumn{2}{|c|}{17.72} \\
\hline Polychaeta tube & & & & & \multicolumn{2}{|c|}{25.08} \\
\hline Zoanthus sociatus & \multicolumn{2}{|c|}{23.98} & 7.22 & & & \\
\hline Cumulative (\%) & & & 94.39 & 96.13 & \multicolumn{2}{|c|}{91.88} \\
\hline \multirow{2}{*}{ Average dissimilarity (\%) } & $1 \times 2$ & $1 \times 3$ & $1 \times 4$ & $2 \times 3$ & $2 \times 4$ & $3 \times 4$ \\
\hline & 50.70 & 55.01 & 67.89 & 39.39 & 47.00 & 45.11 \\
\hline \multicolumn{7}{|l|}{ Contribution (\%) } \\
\hline Cyanobacteria & 6.31 & 4.17 & 9.06 & 9.14 & 10.84 & 18.85 \\
\hline Dendropoma sp. & 5.52 & 8.51 & & 12.01 & 3.67 & 11.85 \\
\hline Dictyosphaeria ocellata & 5.78 & 10.52 & 6.35 & 7.97 & 5.95 & 6.05 \\
\hline Dictyosphaeria versluysii & 3.86 & & & 5.82 & 5.88 & 6.26 \\
\hline Digenea simplex & 22.48 & 7.41 & 7.31 & 22.32 & & 11.08 \\
\hline Gelidiella acerosa & 18.65 & 19.50 & 15.04 & & 15.24 & \\
\hline Gelidiella setacea & 9.41 & 10.37 & 7.44 & & & \\
\hline Hydrolithon pachydermum & & 5.74 & 4.07 & 8.45 & 6.20 & \\
\hline Lyngbya confervoides & & & 11.92 & 5.89 & 15.69 & 17.18 \\
\hline Polychaeta tube & 5.75 & 4.02 & 13.09 & 8.00 & 17.20 & 21.57 \\
\hline Zoanthus sociatus & 12.54 & 20.70 & 15.97 & 13.81 & 11.00 & \\
\hline Cumulative (\%) & 90.27 & 90.94 & 90.26 & 93.40 & 91.68 & 92.85 \\
\hline
\end{tabular}

algae are known to have a substantial resistance to sediment deposition $[44,45]$. Herbivory experiments in Atol das Rocas [36] revealed that Gelidiella acerosa were hardly consumed due to the morphological configuration of their thalli. The same experiments also revealed that Digenea simplex was intensively grazed by fishes, which may explain the absence of the species in this habitat. Furthermore, the zoanthid Zoanthus sociatus also with a high tolerance to environmental variability $[46,47]$ achieves its highest cover in this habitat.

Habitat II prevailed on the central sheltered areas of the reef flat. In contrast to Habitat I, the slightly higher elevations of the flat results in very shallow waters even at high tide, which prevent the access of large herbivorous fishes enabling the better development of $D$. simplex. The absence of $G$. acerosa is probably related to higher competitive abilities of D. simplex under these environmental conditions. The lower Shannon Index and Evenness reflected the dominance of $D$. simplex over other species.

Habitat III set on the windward arch of the atoll and was thus exposed to a more intense hydrodynamic scenario than the others habitats. During the highest tidal stages, the benthic community was entirely washed over by waves. These conditions improve the development of species relatively resistant to higher turbulent waters. The dominance of crustose corallines in reef zones submitted to higher energy conditions were described elsewhere $[8,11,30]$. These species are physically very resistant and are almost the single organisms at windward reef crests $[2,3]$. The prostate shape of the crustose macroalgae Dictyosphaeria ocellata also enhances its abilities to support higher hydrodynamic conditions [48]. The lower Richness and higher Evenness values reflected a great equitability between the few species observed in this habitat.

In general, the study indicates that the reef flat of Atol das Rocas harbors a benthic community adapted to low water turbulence, lengthy periods of aerial exposure, and low herbivore pressure. There were no data about significant human impacts until now on this reef, affecting the general stability of the community studied. These conditions should be maintained due to the strict environmental Brazilian laws implemented for the preservation of this Marine Reserve, unless other climatic and oceanographic factors controlling the atoll change over time. 


\section{Acknowledgments}

The authors would like to thank the Brazilian Environmental Agency "Instituto Chico Mendes de Conservação da Biodiversidade" (ICMBio) for the research facilities at the Marine Biological Reserve of Atol das Rocas, and M. Brito, the reserve manager; The foundation "Fundação O Boticário de Proteção à Natureza" for the financial support; CAPES which provided the first author with two years of a Ph.D. scholarship; P. S. Figueiredo, L. Santi, A. Almeida, C. Pezzela (in memoriam), A. B. Villas Bôas, and F. Fonseca for essential help in fieldwork. B. Knoppers. is a senior research fellow of CNPq (Grant no. 306157/2007-1).

\section{References}

[1] C. M. Lalli and T. R. Parsons, Biological Oceanography: An Introduction, Elsevier, Oxford, UK, 2nd edition, 1997.

[2] J. S. Levinton, Marine Biology: Function, Biodiversity, Ecology, Oxford University Press, Oxford, UK, 2nd edition, 2001.

[3] J. W. Nybakken and M. D. Bertness, Marine Biology: An Ecological Approach, Pearson/Benjamin Cummings, San Francisco, Calif, USA, 6th edition, 2004.

[4] M. M. Littler and D. S. Littler, "Models of tropical reef biogenesis: the contribution of algae," Progress in Phycological Research, vol. 3, pp. 323-364, 1984.

[5] M. A. Huston, "Patterns of species diversity on coral reefs," Annual Review of Ecology and Systematics, vol. 17, pp. 149-177, 1985.

[6] J. H. Connell, T. P. Hughes, and C. C. Wallace, "A 30-year study of coral abundance, recruitment, and disturbance at several scales in space and time," Ecological Monographs, vol. 67, no. 4, pp. 461-488, 1997.

[7] H. T. Odum and E. P. Odum, "Trophic structure and productivity of a windward coral reef community on eniwetok Atol," Ecological Monographs, vol. 25, pp. 291-320, 1955.

[8] M. M. Littler, P. R. Taylor, D. S. Littler, R. H. Sims, and J. N. Norris, "Dominant macrophyte standing stocks, productivity and community structure on a Belizean barrier reef," Atoll Research Bulletin, vol. 302, pp. 1-24, 1987.

[9] C. L. Rodrigues, S. Caeiro, and S. V. Raikar, "Marine macrophyte communities on the reef flat at Agatti atoll (Lakshadweep, India)," Botanica Marina, vol. 40, no. 6, pp. 557-568, 1997.

[10] T. Nakamura and T. Nakamori, "Estimation of photosynthesis and calcification rates at a fringing reef by accounting for diurnal variations and the zonation of coral reef communities on reef flat and slope: a case study for the Shiraho reef, Ishigaki Island, southwest Japan," Coral Reefs, vol. 28, no. 1, pp. 229 250, 2009.

[11] P. S. Vroom, K. N. Page, K. A. Peyton, and J. K. Kukea-Shultz, "Spatial heterogeneity of benthic community assemblages with an emphasis on reef algae at French Frigate Shoals, Northwestern Hawai'ian Islands," Coral Reefs, vol. 24, no. 4, pp. 574-581, 2005.

[12] D. F. M. Gherardi and D. W. J. Bosence, "Modeling of the ecological succession of encrusting organisms in recent coralline-algal frameworks from Atoll das Rocas, Brazil," Palaios, vol. 14, no. 2, pp. 145-158, 1999.

[13] D. F. M. Gherardi and D. W. J. Bosence, "Composition and community structure of the coralline algal reefs from Atol das Rocas, South Atlantic, Brazil," Coral Reefs, vol. 19, no. 3, pp. 205-219, 2001.
[14] R. C. Villaça, A. C. Fonseca, C. A. C. Pezzella, and V. K. Jensen, "Ecology of macroalgae from atol das rocas reef," Phycologia, vol. 40, supplement 4, p. 113, 2001.

[15] R. C. Villaça, A. G. Pedrini, S. M. B. Pereira, and M. A. O. Figueiredo, "Flora bentônica das ilhas oceânicas brasileiras," in Ilhas Oceânicas Brasileiras: Da Pesquisa ao Manejo, R. J. V. Alves and J. W. A. Castro, Eds., pp. 105-146, Ministério do Meio Ambiente, Brasília, Brazil, 2006.

[16] C. A. Echeverria, D. O. Pires, M. S. Medeiros, and C. B. Castro, "Cnidarians of the atol das rocas," in Proceedings of the 8th International Coral Reef Symposium, vol. 1, pp. 443-446, 1997.

[17] S. A. Netto, M. J. Attrill, and R. M. Warwick, "Sublittoral meiofauna and macrofauna of Rocas Atoll (NE Brazil): indirect evidence of a topographically controlled front," Marine Ecology Progress Series, vol. 179, pp. 175-186, 1999.

[18] S. A. Netto, R. M. Warwick, and M. J. Attrill, "Meiobenthic and macrobenthic community structure in carbonate sediments of Rocas atoll (north-east, Brazil)," Estuarine, Coastal and Shelf Science, vol. 48, no. 1, pp. 39-50, 1999.

[19] R. K. P. Kikuchi and Z. M. A. N. Leão, "Rocas (Southwestern Equatorial Atlantic, Brazil): an atoll built primarily by coralline algae," in Proceedings of the 8th International Coral Reef Symposium, vol. 1, pp. 731-736, 1997.

[20] D. F. M. Gherardi and D. W. J. Bosence, "Late Holocene reef growth and relative sea-level changes in Atol das Rocas, equatorial South Atlantic," Coral Reefs, vol. 24, no. 2, pp. 264272, 2005.

[21] O. Höflich, "Climate of the South Atlantic Ocean," in Climates of the Oceans, H. Van Loon, Ed., pp. 1-192, Elsevier, Amsterdam, The Netherlands, 1984.

[22] C. M. Sabino and R. Villaça, "Estudo comparativo de métodos de amostragem de comunidades de costão," Revista Brasileira de Biologia, vol. 59, no. 3, pp. 407-419, 1999.

[23] P. Legendre and L. Legendre, Numerical Ecology. Developments in Environmental Modelling, Elsevier, Amsterdam, The Netherlands, 2nd edition, 1998.

[24] J. H. Zar, Biostatistical Analysis, Prentice Hall, London, UK, 5th edition, 2009.

[25] D. R. Stoddart, "Three caribbean atolls: turneffe Islands, Lighthouse Reef and Glover's Reef, British Honduras," Atoll Research Bulletin, vol. 87, pp. 1-151, 1962.

[26] J. D. Milliman, "The geomorphology and history of hogsty reef, a bahamian atoll," Bulletin of Marine Science, vol. 17, no. 3, pp. 519-543, 1967.

[27] J. D. Milliman, "Four southwestern carribbean atolls: courtown cays, albuquerque cays roncador bank and serrana bank," Atoll Research Bulletin, vol. 129, pp. 1-41, 1969.

[28] P. S. Kench and R. W. Brander, "Wave processes on coral reef flats: implications for reef geomorphology using Australian case studies," Journal of Coastal Research, vol. 22, no. 1, pp. 209-223, 2006.

[29] J. M. Díaz, G. Díaz-Pulido, and J. A. Sánchez, "Distribution and structure of the southernmost Caribbean coral reefs: golfo de Uraba, Colombia," Scientia Marina, vol. 64, no. 3, pp. 327336, 2000.

[30] J. Morrissey, "Community structure and zonation of microalgae and hermatypic corals on a fringing reef flat of magnetic island (Queensland, Australia)," Aquatic Botany, vol. 8, pp. 91$139,1980$.

[31] K. J. Roy and S. V. Smith, "Sedimentation and coral reef development in turbid waters: fanning lagoon," Pacific Science, vol. 25, no. 2, pp. 234-248, 1971. 
[32] Y. Loya, "Effects of water turbidity and sedimentation on the community structure of Puerto Rico corals," Bulletin of Marine Science, vol. 26, no. 4, pp. 450-456, 1976.

[33] T. A. Norton, "Conflicting constraints on the form of intertidal algae," British Phycological Journal, vol. 26, no. 3, pp. 203-218, 1991.

[34] L. Airoldi, M. Fabiano, and F. Cinelli, "Sediment deposition and movement over a turf assemblage in a shallow rocky coastal area of the Ligurian Sea," Marine Ecology Progress Series, vol. 133, no. 1-3, pp. 241-251, 1996.

[35] D. Morrison, "Comparing fish and urchin grazing in shallow and deeper coral reef algal communities," Ecology, vol. 69, no. 5, pp. 1367-1382, 1988.

[36] L. V. Marques, R. Villaça, and R. C. Pereira, "Susceptibility of macroalgae to herbivorous fishes at Rocas Atoll, Brazil," Botanica Marina, vol. 49, no. 5-6, pp. 379-385, 2006.

[37] R. C. Carpenter, "Partitioning herbivory and its effects on coral reef algal communities," Ecological Monographs, vol. 56, no. 4, pp. 345-363, 1986.

[38] M. E. Hay, "Fish-seaweed interactions on coral reefs: effects of herbivorous fishes and adaptations of their prey," in The Ecology of Fishes on Coral Reefs, P. F. Sale, Ed., pp. 96-119, Academic Press, San Diego, Calif, USA, 1991.

[39] T. R. McClanahan, "Primary succession of coral-reef algae: differing patterns on fished versus unfished reefs," Journal of Experimental Marine Biology and Ecology, vol. 218, no. 1, pp. 77-102, 1997.

[40] T. R. McClanahan, "Predation and the control of the sea urchin Echinometra viridis and fleshy algae in the patch reefs of Glovers Reef, Belize," Ecosystems, vol. 2, no. 6, pp. 511-523, 1999.

[41] B. E. Lapointe, P. J. Barile, C. S. Yentsch, M. M. Littler, D. S. Littler, and B. Kakuk, "The relative importance of nutrient enrichment and herbivory on macroalgal communities near Norman's Pond Cay, Exumas Cays, Bahamas: a "natural" enrichment experiment," Journal of Experimental Marine Biology and Ecology, vol. 298, no. 2, pp. 275-301, 2004.

[42] R. S. Rosa and R. L. Moura, "Visual assessment of reef fish community structure in the Atol Das Rocas Biological Reserve, off northeastern Brazil," in Proceedings of the 8th International Coral Reef Symposium, vol. 1, pp. 983-986, 1997.

[43] R. S. Steneck, "The ecology of coralline algal crusts: convergent patterns and adaptative strategies," Annaul Review of Ecology and Systematics, vol. 17, pp. 273-303, 1986.

[44] L. Airoldi and F. Cinelli, "Effects of sedimentation on subtidal macroalgal assemblages: an experimental study from a mediterranean rocky shore," Journal of Experimental Marine Biology and Ecology, vol. 215, no. 2, pp. 269-288, 1997.

[45] L. Airoldi and M. Virgilio, "Responses of turf-forming algae to spatial variations in the deposition of sediments," Marine Ecology Progress Series, vol. 165, pp. 271-282, 1998.

[46] K. P. Sebens, "Intertidal distribution of zoanthids on the caribbean coast of Panama: effects of predation and desiccation," Bulletin of Marine Science, vol. 32, no. 1, pp. 316-335, 1982.

[47] Y. I. Sorokin, "Biomass, metabolic rates and feeding of some common reef zoantharians and octocorals," Australian Journal of Marine \& Freshwater Research, vol. 42, no. 6, pp. 729-741, 1991.

[48] S. T. Larned and M. J. Atkinson, "Effects of water velocity on $\mathrm{NH}_{4}$ and $\mathrm{PO}_{4}$ uptake and nutrient-limited growth in the macroalga Dictyosphaeria cavernosa," Marine Ecology Progress Series, vol. 157, pp. 295-302, 1997. 

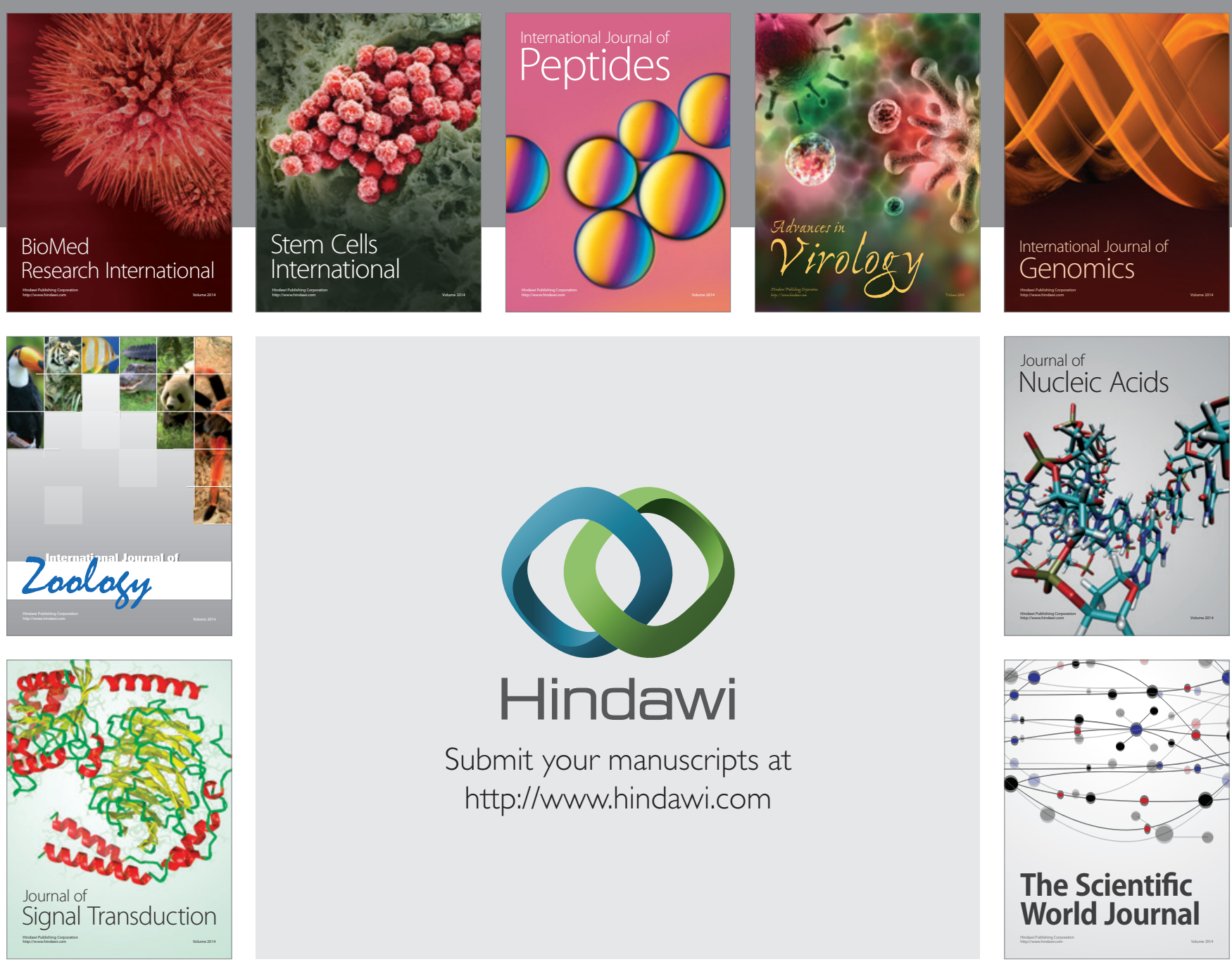

Submit your manuscripts at

http://www.hindawi.com
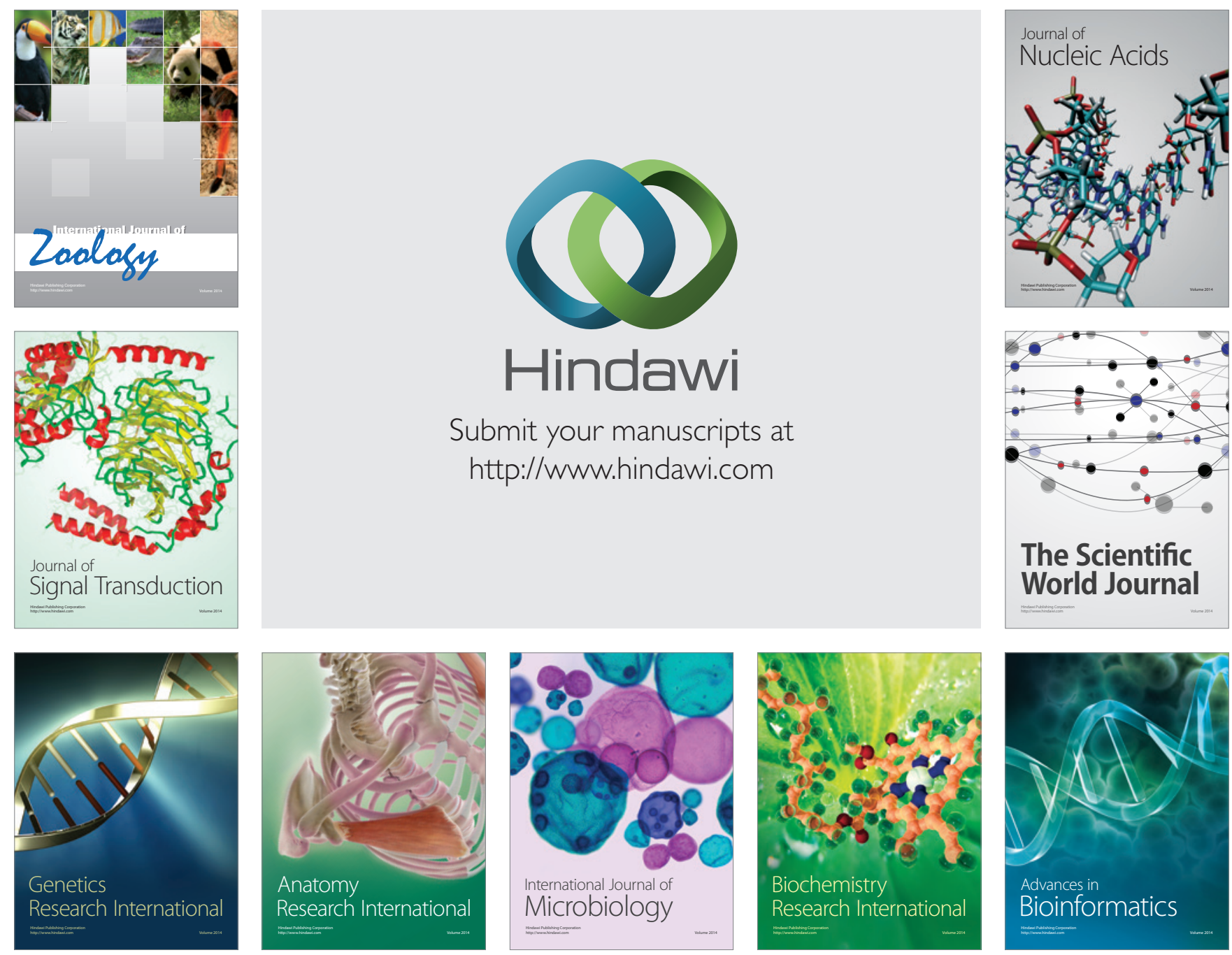

The Scientific World Journal
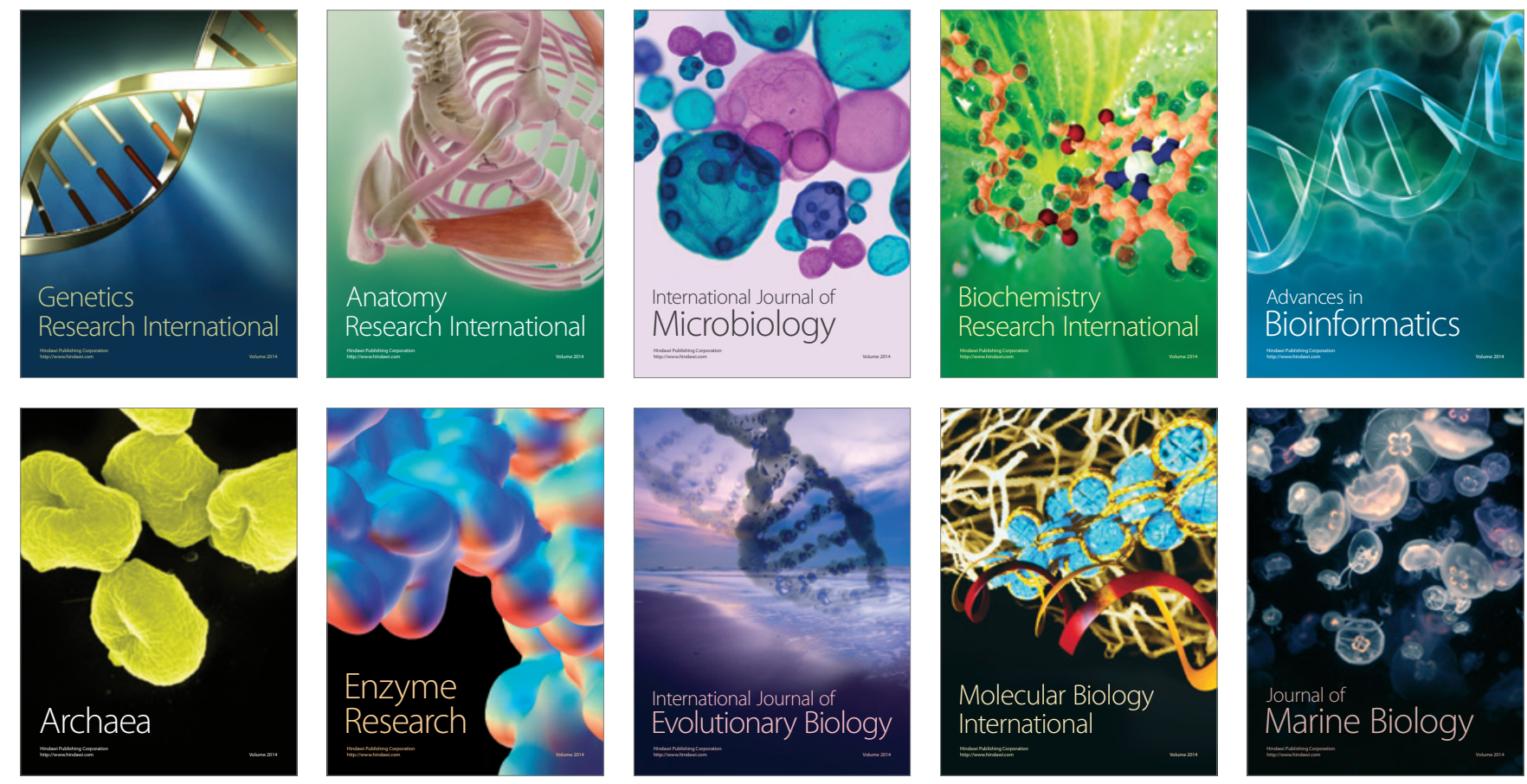